\title{
A STUDY OF SEISMIC POUNDING EFFECT BETWEEN ADJACENT BUILDINGS AND ITS MITIGATION BY USING DIFFERENT TYPE OF BRACING SYSTEMS
}

\author{
Ravindranatha ${ }^{1}$, Pradeep Karanth ${ }^{2}$, Shivananda S.M ${ }^{3}$, H.L Suresh ${ }^{4}$ \\ ${ }^{1}$ Assistant Professor (Selection grade), Civil Engineering, Manipal Institute of Technology, Karnataka, India \\ ${ }^{2}$ Post Graduate student, Structural Engineering, Manipal Institute of Technology, Karnataka, India \\ ${ }^{3}$ Structural Engineer, Atkins India Pvt Ltd, Bangalore, Karnataka, India \\ ${ }^{4}$ Director, Structural Engineer, Civil Tech India Pvt Ltd, Bangalore, Karnataka, India
}

\begin{abstract}
Investigation of previous and recent earthquake damage have shown that the buildings are subjected to severe destruction or collapse during the earthquake ground motion. Among the probable structural damages, seismically induced pounding has been usually witnessed in most of the earthquakes. During the earthquake, Building vibrates out phase due there different dynamics characteristics. Such buildings are usually separated by expansion joint which is insufficient to accommodate the lateral movements of the buildings during the earthquake. Seismic pounding can be prevented by providing safe separation distances; sometimes availability of required safe separation gap is not possible in metropolitan cities due to high land value and limited availability of land. If building separation is found to be deficient to prevent pounding, then there should be some easy and costeffective methods to prevent structural pounding between adjacent buildings. This study covers the effect of structural pounding on conventional beam column system adjacent to flat slab system .In order to observe pounding effect, Time history analysis is carried out by taking 1944 Elcentro earthquake data which is to be known as above average earthquake. This study also covers the prevention techniques of pounding by using retrofitting's like introducing $X$ cross bracings, Eccen forward and backward cross bracing, $V$ cross bracing systems with proper placement are proposed as possible mitigation techniques for pounding between adjacent structures.
\end{abstract}

Keywords: Seismic pounding, Earthquake, SAP 2000, Flat slab, Bracing. $* * *$

\section{INTRODUCTION}

The Seismic pounding is simply known as collision or hammering of two buildings which are adjacent to each other having different dynamic characteristics. The main reason for the seismic pounding is a lack of separation gap in between the adjacent buildings. Most of the time pounding between the structures is commonly observed in the old buildings that were constructed before the earthquake resistant design principles came into the picture. Even though many present codes specify a minimum seismic gap, it still fails to include the effect of all other parameters that affect the structural deformation.

Pounding damage was observed during the previous earthquakes namely 1985 Mexico earthquake, the 1988 Sequenay earthquake in Canada, and 1944 Elcentro earthquake. During the earthquake, Building vibrates out phase due there different dynamics characteristics. Such buildings are usually separated by expansion joint which is insufficient to accommodate the lateral movements of the adjacent buildings. (1.Abdel and Shehata, 2006). Previous seismic codes couldn't give fixed guidelines to prevent pounding, especially in the metropolitan cities due to high land value and non-availability of the land. There are so many structures which are already constructed close to each other without any safe separation gap, which could suffer pounding damage in the forthcoming earthquakes.

The simplest and most appropriate way for pounding mitigation is to provide safe separation gap, but in metropolitan cities it is tough to fulfill due to high land value and non-availability of the land. An alternative to the seismic separation gap provision in the structure design is to reduce the effect of pounding through decreasing lateral displacement by introducing the stiffeners like RC walls, Bracings, dampers etc. The main objective of the study are to evaluate the effect of structural pounding on global response of the building, to determine the lateral peak displacement during the earthquake ground motion and to provide engineers with real tools to mitigate the seismic pounding.

\section{METHODOLOGY}

To observe pounding, a three-dimensional reinforced concrete moment resisting frame buildings is taken and analyzed in SAP2000. For the analysis, an eight $(\mathrm{G}+8)$ storey buildings consist conventional beam column structural system and a six $(\mathrm{G}+6)$ storey building consist of flat slab systems are considered. All columns in the models are considered to be fixed at the base. The floor to floor 
height of the both buildings is 3.2 meter. A slab of eight $(\mathrm{G}+8)$ storey are modeled as rigid diaphragm floor element of $150 \mathrm{~mm}$ thickness and slab of six $(\mathrm{G}+6)$ storey are modeled as rigid diaphragm floor element of $150 \mathrm{~mm}$ thickness and drop thickness is $200 \mathrm{~mm}$ and is designed as per to IS 456-2000. Live load on the floor is taken as $3 \mathrm{kN} / \mathrm{m}^{2}$ and on the roof is $1.5 \mathrm{kN} / \mathrm{m}^{2}$. Floor finish on the floor and weathering course on the roof is taken as $1 \mathrm{kN} / \mathrm{m}^{2}$ respectively for the both the building. The seismic weight is calculated according to IS 1893-2002. The unit weight of concrete is taken as $25 \mathrm{kN} / \mathrm{m}^{3}$. The grade of the concrete for the columns are M-25 and that of beams and slab are M-20. The building is analyzed as special moment resisting frame considered to be situated in seismic zone IV having medium soil and proposed for residential use. These buildings are separated by expansion joint of $100 \mathrm{~mm}$. Both buildings are analyzed in SAP2000 and are designed as per IS 456-2000. Both buildings are subjected to gravity and dynamic loads. To observe pounding, Time History Analysis is carried out by taking the data of Electro earthquake.

Building-A, Beam-column system consist of eight $(\mathrm{G}+8)$ storey has 4 bays in $\mathrm{X}$ and $\mathrm{Y}$ directions, having external columns size of $0.4 \times 0.8 \mathrm{~m}^{2}$, whereas all internal column size of $0.55 \times 1.0 \mathrm{~m}^{2}$. The width of each bay in the $\mathrm{X}$ direction is $4 \mathrm{~m}$, and that of in $\mathrm{Y}$ direction is $5 \mathrm{~m}$ while the beam size is $0.35 \times 0.6 \mathrm{~m}^{2}$ in both the direction. Building-B, Flat slab system having six $(\mathrm{G}+6)$ storey has 4 bays in $\mathrm{X}$ and $\mathrm{Y}$ directions, the width of each bay in the $X$ direction is $3 \mathrm{~m}$, in $\mathrm{Y}$ direction is $5 \mathrm{~m}$, having external column size of $0.3 \times 0.75$ $\mathrm{m}^{2}$, whereas all internal column size of $0.3 \times 0.9 \mathrm{~m}^{2}$ and no beams in both directions.

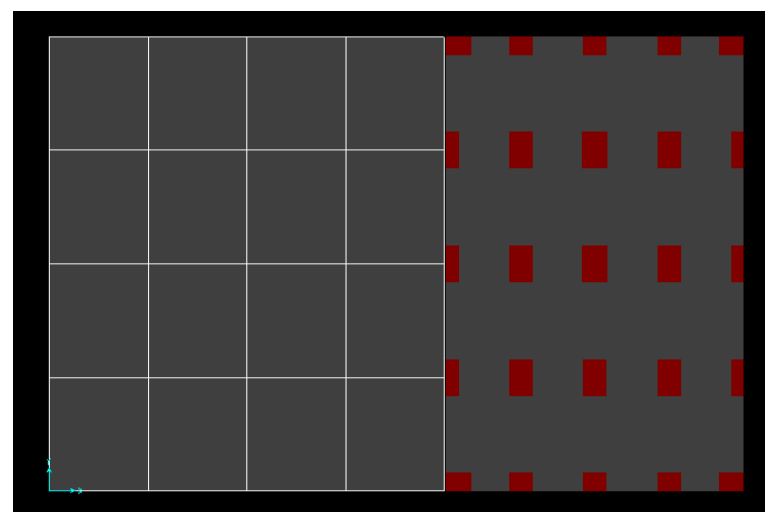

Fig -1: Plan view of beam column system adjacent to flat slab system

\section{REQUIRED SEISMIC SEPARATION}

\section{DISTANCE TO AVOID POUNDING:}

To prevent the pounding, seismic codes and regulation worldwide specify minimum safe separation gap to be provided between the adjacent buildings which is equal to the peak displacement of the two colliding building systems. For instance, according to the 2000 edition of the international building code and in many seismic design codes, the minimum safe separation gap (Lopez Garcia 2004) is as follows
$\mathrm{S}=\sqrt{ }(\mathrm{Q} 12+\mathrm{Q} 22)$ is an SRSS (Square Root of the Sum of the Squares) Method

$\mathrm{S}=\mathrm{Q} 1+\mathrm{Q} 2$ is Absolute Sum Method (ABS)

Where,

$\mathrm{Q} 1=$ Peak displacement of building-A

$\mathrm{Q} 2=$ Peak displacement of building-B

$\mathrm{S}=$ separation distances

\section{A. Required Seismic Separation Distance to Avoid Pounding}

According to Bureau of Indian standard code IS 4326 that a safe separation distance is to be provided to prevent pounding between the building during an earthquake and same is shown in Table 1.

Table I: The design seismic coefficient to be used in accordance with IS 1893:1984

\begin{tabular}{|c|c|c|}
\hline $\begin{array}{c}\text { Sl. } \\
\text { No }\end{array}$ & Type of Constructions & $\begin{array}{c}\text { Gap Width/Storey, } \\
\text { in mm for Design } \\
\text { Seismic Coefficient } \\
\alpha \mathrm{h}=0.12\end{array}$ \\
\hline 1 & $\begin{array}{c}\text { Box systems of frames } \\
\text { with shear walls }\end{array}$ & 15.0 \\
\hline 2 & $\begin{array}{c}\text { Moment resistant } \\
\text { reinforced concrete frame }\end{array}$ & 20.0 \\
\hline 3 & $\begin{array}{c}\text { Moment resistant steel } \\
\text { frame }\end{array}$ & 30.0 \\
\hline
\end{tabular}

Note: Minimum total gap shall be $25 \mathrm{~mm}$. For any other values of $\alpha$, the gap width shall be determined accordingly.

\subsection{Beam column system adjacent to Flat slab system without any bracings.}

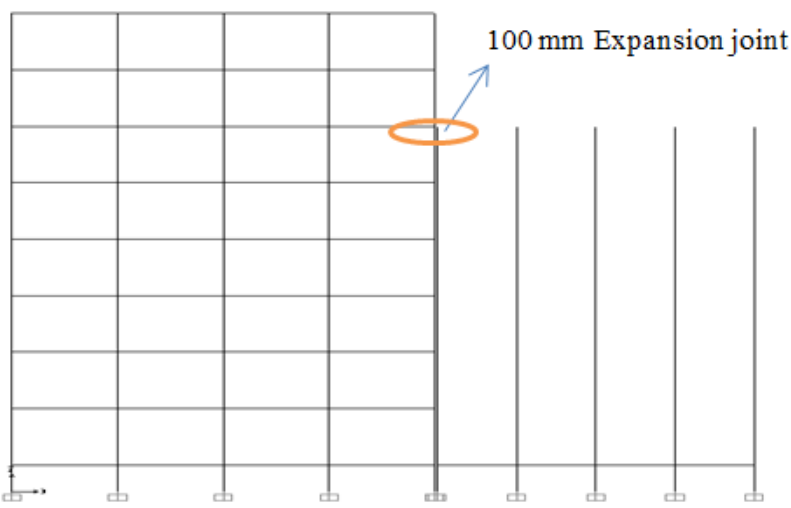

Fig-2: Elevation view of beam column system adjacent to Flat slab system without any cross bracings.

After analyzing these two buildings in SAP2000 under time history record of Elcentro earthquake data which is to be known as above average earthquake, the behavior of the buildings i.e. displacement with respect to time was observed. Pounding analysis carried out on the roof of sixth floor, to observe the positive displacement of $\mathrm{G}+8$ storey and negative displacement of the G+6 storey, as we are going to consider worst condition due to its different dynamic characteristics. 


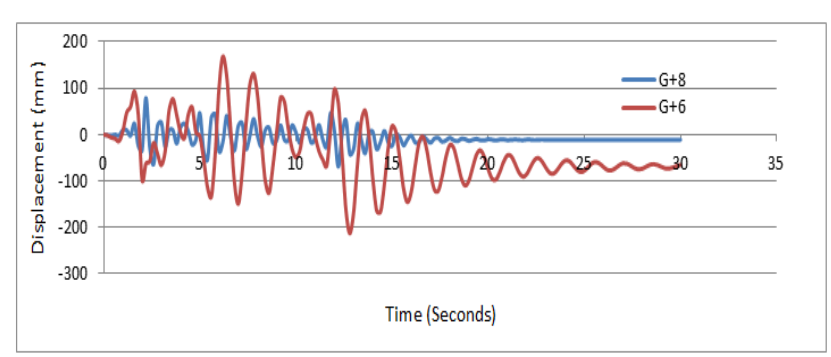

Fig- 3: Time vs displacement graph of beam column system adjacent to flat slab system at sixth -floor roof level without any cross bracings.

Figure-3 shows time vs. displacement graph at the sixthfloor level, in this maximum positive displacement of $\mathrm{G}+8$ storey building is $80.30 \mathrm{~mm}$ at 2.2 seconds and maximum negative displacement of G+6 storey building is $212.53 \mathrm{~mm}$ at 12.8 seconds. From the figure, it is noticed that maximum out of phase movement of both building is $(80.30+212.53)$ $100=192.83 \mathrm{~mm}$ which is greater than the given expansion joint, hence which is unable to accommodate this out of phase movement, and adjacent buildings will strike or collide each other.

\subsection{Provide Cross Bracings to Increase Stiffness:}

Since the gap between the buildings not able to increase to accommodate the relative displacement of the both the building, but we can reduce this relative displacement by providing additional stiffeners i.e. by introducing the cross bracings. In this study ISWB 175 wide flanges are used for the steel bracing to reduce the lateral displacement (9.Amruta Sadanada Tapashetti et.al, (2014)).

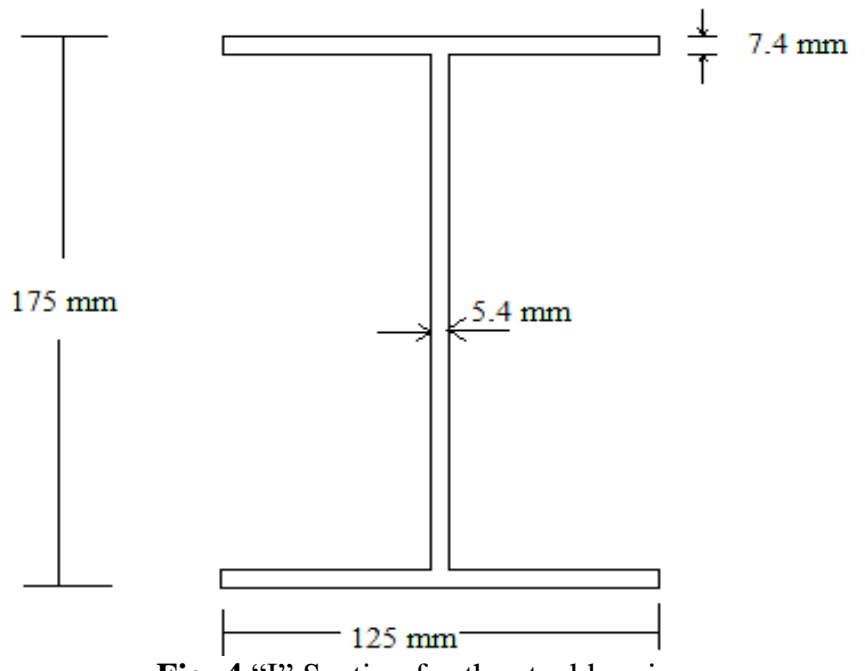

Fig- 4 "I" Section for the steel bracings

\section{a) Providing $\mathrm{X}$-Cross bracings:}

$\mathrm{X}$ cross Bracings are provided (8.Tauseef $\mathrm{M}$ honnyal et.al, 2014) at the exterior panels of the both buildings in $X$ direction to reduce the lateral displacements. The connection of steel cross braces with concrete frame structure requires a very special consideration and the strong connection should be there to transfer the load safely.

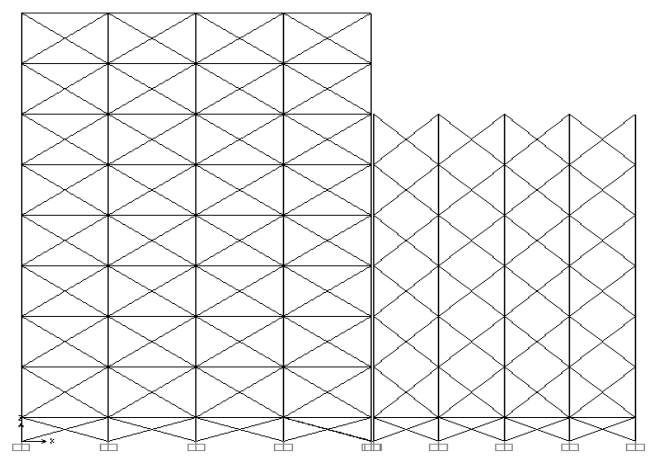

Fig- 5: Shows the X- Cross bracings of eight-storey and sixstorey buildings

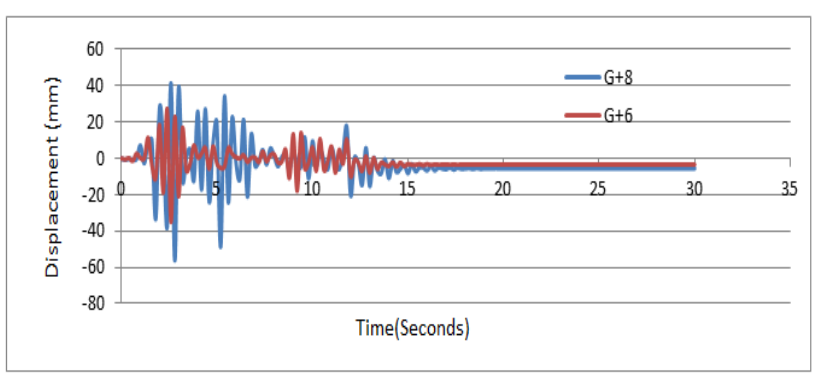

Fig- 6: Time vs. displacement graph for both the buildings at Sixth-floor roof level with additional X-Cross bracing

Figure- 6 shows time vs. displacement graph at the sixthfloor level, in this maximum positive displacement of $\mathrm{G}+8$ storey is $41.26 \mathrm{~mm}$ at 2.6 seconds and maximum negative displacement of the $\mathrm{G}+6$ storey is $35.12 \mathrm{~mm}$ at 2.6 seconds. It shows that maximum out of phase movement is $(41.26+35.12)=76.38 \mathrm{~mm}$ which is lesser than the expansion joint i.e. $100 \mathrm{~mm}$, hence no chance of pounding at any interval any point of time, when these kinds of additional stiffness are provided.

\section{b) Providing Eccen forward cross bracings:}

Eccen forward cross bracings are provided at the end panels of the both buildings in $\mathrm{X}$ direction to reduce the lateral displacements. The connection of steel cross braces with concrete frame structure should be strong to transfer the load from concrete frame to cross braces safely.

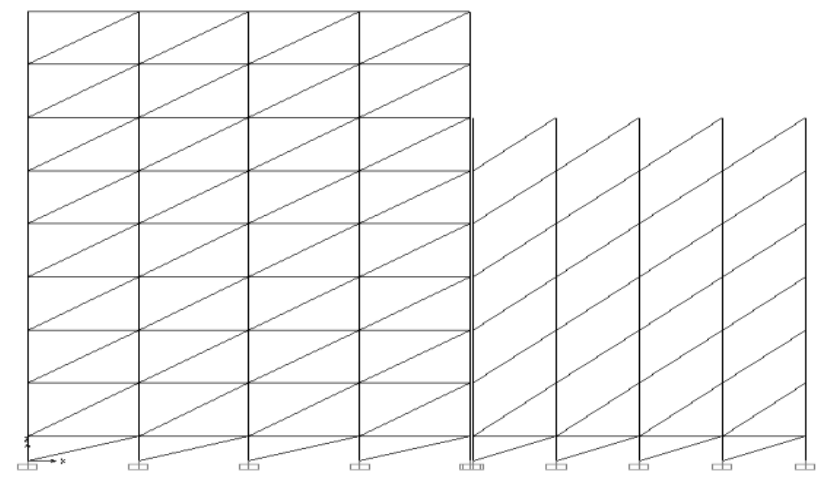

Fig- 7: Shows the Eccen forward cross bracings of eightstorey and six-storey buildings 


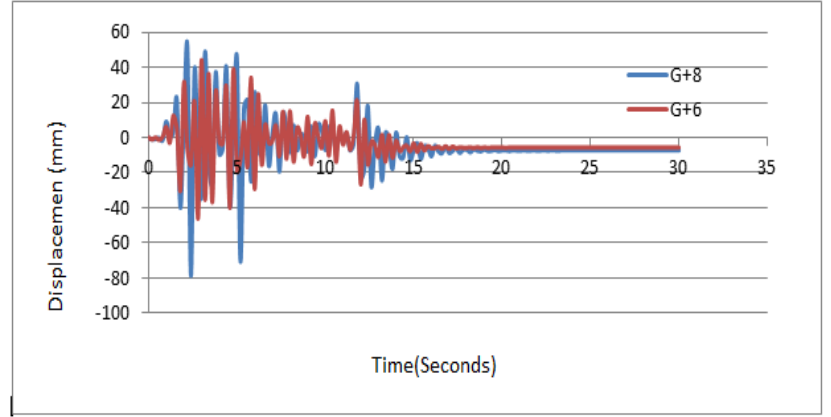

Fig- 8: Time vs. displacement graph for both the buildings at Sixth-floor roof level with additional Eccen forward cross bracings

Figure-8, shows time vs. displacement graph at the sixthfloor level, in this maximum positive displacement of $\mathrm{G}+8$ storey is $51.66 \mathrm{~mm}$ at 2.2 seconds and Maximum negative displacement of $\mathrm{G}+6$ storey is $45.95 \mathrm{~mm}$ at 2.8 seconds. The absolute sum of both is $(51.66+45.95)=97.62 \mathrm{~mm}$. Hence, it is less than given expansion joint, and hence no chance of pounding at any interval of time.

\section{c) Providing Eccen backward cross bracings:}

Eccen backward bracings are provided at the end panels of the both buildings in $\mathrm{X}$-direction to reduce the lateral displacements.

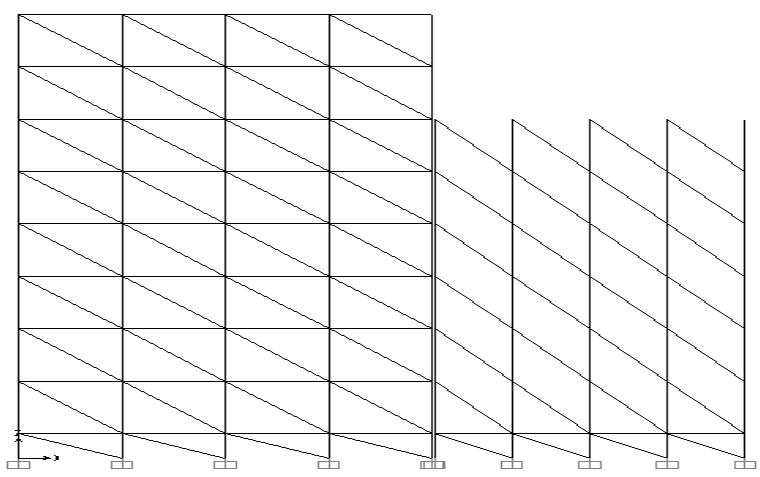

Fig- 9: Shows the Eccen backward cross bracings of eightstorey and six-storey buildings

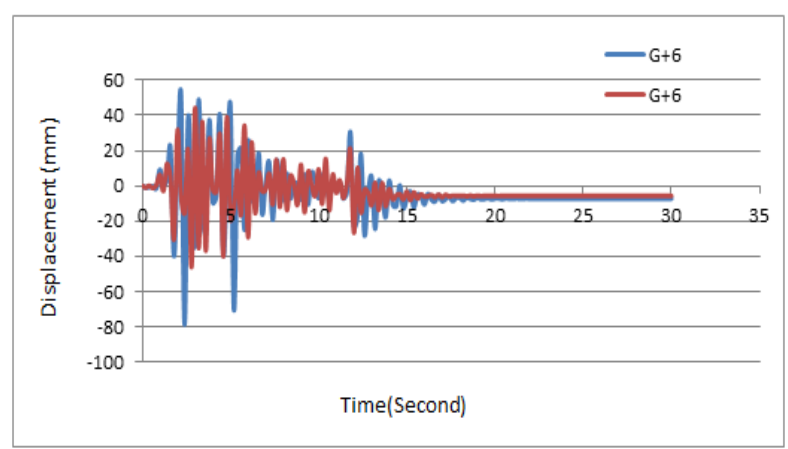

Fig- 10: Time vs. displacement graph for both the buildings at Sixth-floor roof level with additional Eccen backward cross bracings
Figure-10, shows time vs. displacement graph at the sixthfloor level, in this maximum positive displacement of $\mathrm{G}+8$ storey is $51.66 \mathrm{~mm}$ at 2.2 seconds and maximum negative displacement of $\mathrm{G}+6$ storey is $45.95 \mathrm{~mm}$ at 2.8 seconds. The absolute sum of both is $(51.66+45.95)=97.62 \mathrm{~mm}$. Hence, it is less than given expansion joint, and hence no chance of pounding at any interval of time.

\section{d) Providing $\mathbf{V}$ cross bracings:}

$\mathrm{V}$ bracings are provided at the end panels of the both buildings in X-direction to reduce the lateral displacements.

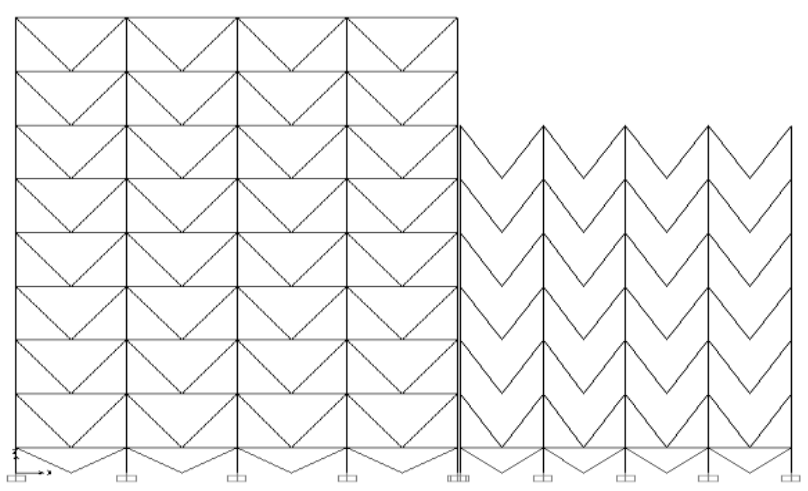

Fig- 11: Shows the V cross bracings of eight-storey and six-storey buildings

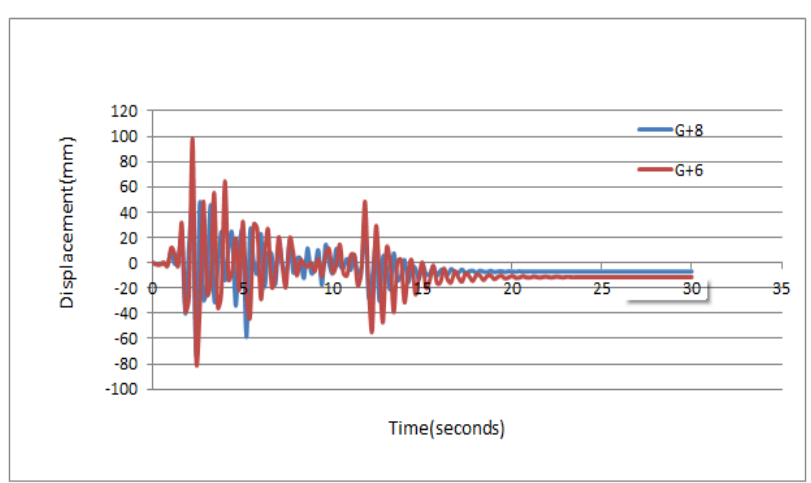

Fig- 12: Time vs. displacement graph for both the buildings at Sixth-floor roof level with additional V cross bracings

Figure-12, shows time vs. displacement graph at the sixthfloor level, in this maximum positive displacement of $\mathrm{G}+8$ storey is $47.878 \mathrm{~mm}$ at 2.6 second and maximum negative displacement of $\mathrm{G}+6$ storey is $76.198 \mathrm{~mm}$ at 2.4 seconds. The absolute sum of both is $(47.87+76.19)=123.89$ $\mathrm{mm}$. Hence, it is more than the given expansion joint, and hence pounding is going to take place.

\section{CONCLUSIONS}

- From the above analysis, it was found that $\mathrm{X}$ cross bracing system is more effective in reducing the lateral displacement.

- $\mathrm{V}$ cross bracing contributes partially toward reduction of lateral displacement. 
- Eccen forward and backward bracing system gives more or less same stiffness to the structures

- The stiffness of the flat slab system is less in comparison with beam - column system and hence design engineer have to give more importance while the design of such structures.

- All the prevention methods that are used in this study proved effective to prevent pounding between adjacent buildings.

- All the additional stiffness's should be fixed rigidly for the better performance.

- At the time of design, Design Engineer has to ensure that there will be no pounding between adjacent buildings.

- It is better to leave set back/safe separation gap according to FEMA 273-1997 when the buildings are in early stage of design.

\section{ACKNOWLEDGEMENT}

I would like to thanks to my father $\mathrm{Mr}$. MAHABALESHWARA KARANTH, my mother M/s SUMATHI M.K, my dear brother, professors, and friends to their continuous support in many ways for the completion of this project.

\section{REFERENCES}

[1] Abdel R and E.Shehata "Seismic Pounding between Adjacent Building Structures" Electronic Journal of Structural Engineering 66-74 (2006).

[2] A. Hameed, M. Saleem, A.U. Qazi, S. Saeed and M. A. Bashir "Mitigation of seismic pounding between adjacent buildings" Pakistan journal of science vol.64, December 2012.

[3] Sudhir K Jain et.al, "A field report on structural and geotechnical damages sustained during the 26 January 2001 M7.9 Bhuj Earthquake in Western India".

[4] IS 456:2000 "Indian Standard Plain and Reinforced Concrete Code of Practice".

[5] FEMA-273 [1997] "NEHRP Guidelines for the seismic rehabilitation of buildings, Report No. FEMA273," Federal Emergency Management Agency, October.

[6] IS 1893 (Part 1):2002 Indian Standard "Criteria for Earthquake Resistant Design of Structures" Part 1 General Provision and Buildings, (Fifth Revision).

[7] ATC 40 [1996] "Seismic evaluation and retrofit of concrete buildings, Vol No.1 and "Applied Technology Council, Seismic Safety Commission, State of California.

[8] Tauseef M honnyal et.al, [2014] "A study of seismic pounding between adjacent buildings".

[9] Amruta sadanand Tapashetti et.al, [2014] "seismic pounding effect in building"

[10] SAP 2000 Nonlinear Version 14.0 Software Package.

[11] SAP 2000 Nonlinear Manuals SAP 2000 Videos.

\section{BIOGRAPHIES}

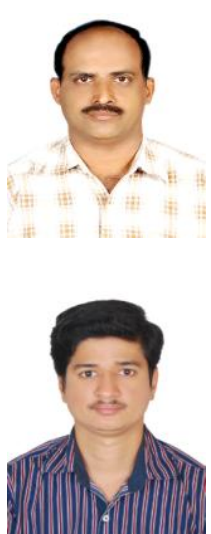

Ravindranatha: Assistant professor (selection grade), Civil Engineering, Manipal Institute of Technology, Manipal.

Pradeep karanth :PG student, Civil Engineering, Manipal institute of technology, Manipal. 